J. Dairy Sci. 98:7071-7082

http://dx.doi.org/10.3168/jds.2015-9787

(C) American Dairy Science Association ${ }^{\circledR}, 2015$.

\title{
Conjugated linoleic acid isomers strongly improve the redox status of bovine mammary epithelial cells (BME-UV1)
}

\author{
L. Basiricò, ${ }^{*}$ P. Morera, ${ }^{*}$ D. Dipasquale, ${ }^{*}$ A. Tröscher,† A. Serra,ł M. Mele,ł and U. Bernabucci*1 \\ *Dipartimento di scienze e tecnologie per l'Agricoltura, le Foreste, la Natura e l'Energia, Università degli Studi della Tuscia, 01100, Viterbo, Italy \\ †BASF-SE, 67117 Ludwigshafen, Germany \\ ‡Dipartimento di Scienze Agrarie, Alimentari e Agro-ambientali, Università di Pisa, 56126, Pisa, Italy
}

\begin{abstract}
Some studies have shown the protective effects of conjugated linoleic acid (CLA) isomers against oxidative stress and lipid peroxidation in animal models, but no information is available about CLA and changes in oxidative status of the bovine mammary gland. The objectives of the study were to assess in vitro the effect of CLA on the cellular antioxidant response of bovine mammary cells, to examine whether CLA isomers could play a role in cell protection against the oxidative stress, and to study the molecular mechanism involved. For the study, BME-UV1 cells, a bovine mammary epithelial cell line, were used as the experimental model. The BME-UV1 cells were treated with complete medium containing $50 \mu M$ cis-9,trans-11 CLA (c9,t11 CLA), trans-10,cis-12 CLA (t10,c12 CLA), and CLA mixture $(1: 1$, cis-9,trans-11: trans-10,cis-12 CLA). To monitor cellular uptake of CLA isomers, cells and culture medium were collected at 0,3 , and $48 \mathrm{~h}$ from CLA addition for lipid extraction and fatty acid analyses. To assess the cellular antioxidant response, glutathione (GSH/GSSH), NADPH, and $\gamma$-glutamylcysteine ligase activity was measured after $48 \mathrm{~h}$ from addition of CLA. Cytoplasmic superoxide dismutase, glutathione peroxidase, glutathione S-transferase, and glutathione reductase activities and mRNA were also determined. Intracellular reactive oxygen species and thiobarbituric acid reactive substance production were assessed in cells supplemented with CLA isomers. Cell viability after $3 \mathrm{~h}$ to $\mathrm{H}_{2} \mathrm{O}_{2}$ exposure was assessed to evaluate and to compare the potential protection of different CLA isomers against $\mathrm{H}_{2} \mathrm{O}_{2}$-induced oxidative stress. Mammary cells readily picked up all CLA isomers, their accumulation was time dependent, and main metabolites at $48 \mathrm{~h}$ are two 18:3 isomers. The
\end{abstract}

Received May 6, 2015.

Accepted June 18, 2015.

${ }^{1}$ Corresponding author: bernab@unitus.it
CLA treatment induced an intracellular GSH increase, matched by high concentration of NADPH, and an increase of $\gamma$-glutamyl-cysteine ligase activity mainly in cells treated with the t10,c12 CLA isomer. The CLA isomer treatment of bovine mammary cells increased superoxide dismutase, glutathione peroxidase, and glutathione S-transferase activity and decreased glutathione reductase activity, but no changes in gene expression of these antioxidant enzymes were observed. Cells supplemented with CLA isomers showed a reduction in intracellular reactive oxygen species and thiobarbituric acid reactive substance levels. All CLA isomers were able to enhance cell resistance against $\mathrm{H}_{2} \mathrm{O}_{2}$-induced oxidative stress. These suggest an antioxidant role of CLA, in particular of t10,c12 CLA, by developing a significantly high redox status in cells.

Key words: cis-9,trans-11 CLA, trans-10,cis-12 CLA, bovine mammary gland cell, oxidative stress

\section{INTRODUCTION}

In dairy cows, the transition period is particularly important for health and subsequent performance of these animals, which are exposed to drastic physiological changes and metabolic stress (Grummer, 1993; Goff and Horst, 1997; Drackley, 1999). Usually, cows in this transition phase are secreting more energy than they consume; as a consequence, animals experience a substantial negative energy balance and often even oxidative stress (Bernabucci et al., 2005). Substantial evidence corroborates that oxidative stress during the prepartum and early lactation period may contribute to several health disorders in dairy cattle (Bernabucci et al., 2005; Sordillo et al., 2009). A management method used in dairy cows to alleviate the magnitude of negative energy balance is feeding rumen-protected CLA. The influence of CLA on milk composition has been evaluated in several studies, and it has been shown that trans10,cis-12 CLA treatment results in milk fat depression, whereas cis-9,trans-11 CLA was not effective in milk fat depression (Baumgard et al., 2000a; Bauman et al., 
2008). Some authors (Baumgard et al., 2000a,b; Mackle et al., 2003) reported that trans-10,cis-12 have little or no effect on basal plasma concentrations of metabolites (glucose, NEFA, BHBA) and hormones (leptin, insulin, IGF-I) associated with energy homeostasis. In contrast, other studies demonstrated a significant effect of CLA supplementation (as a mix of trans-10,cis-12 and cis9,trans-11 CLA) on circulating IGF-1 and adiponectin in transition dairy cows, resulting in a prolongation of peripartal insulin resistance and drain of nutrients toward the mammary gland (Castañeda-Gutiérrez et al., 2005; Singh et al., 2014).

The effects of trans-10, cis-12 CLA in dairy cows appear to be specific to the mammary gland. Moreover, trans-10,cis-12 CLA effects may depend on the dietary status and the stage of lactation of the studied cows (Bauman and Griinari, 2003; Selberg et al., 2004; Castañeda-Gutiérrez et al., 2005; Odens et al., 2007). Hötger et al. (2013) reported that CLA supplementation (as a mixture of trans-10,cis-12 and cis-9,trans-11 CLA) in dairy cows reduces endogenous glucose production during early lactation, most likely due to lower glucose utilization for milk fat synthesis and a more efficient whole-body energy utilization in CLA-fed cows. Pappritz et al. (2011) as well as von Soosten et al. (2012) concluded that trans-10,cis-12 CLA-fed cows have an increased efficiency of ME utilization.

Given that the administration of trans-10, cis-12 CLA in mammary cells induces a reduction in the synthesis of milk fat, and this may leads to an increased availability of glucose, we hypothesized that glucose sparing might be used for cellular activities related to oxidative response other than lactose and milk synthesis. To date, no information is available concerning the relationship between administration of CLA isomers and changes in oxidative status of the bovine mammary gland. Some studies have shown the protective effects of CLA isomers (mainly cis-9,trans-11 CLA) against oxidative stress and lipid peroxidation in animal models (Andreoli et al., 2010; Chinnadurai et al., 2013). On the other hand, adverse effects of trans-10,cis-12 CLA regarding increased susceptibility to lipid autoxidation and enhancing FA oxidation have also been reported in 3T3L1 cells and in animal models (Da Silva Marineli et al., 2012; den Hartigh et al., 2013). However, mechanism of action is not well understood, yet. Therefore, the study aims to assess in vitro effects of trans-10, cis-12 and cis-9,trans-11 CLA isomers on the cellular antioxidant response of bovine mammary cells, to examine whether these CLA isomers could play a role in cell protection against the oxidative stress and to study the molecular mechanism involved.

\section{MATERIALS AND METHODS}

\section{Cell Culture Conditions}

The BME-UV1 cell line was created at the University of Vermont from primary bovine mammary epithelial cells in culture by stable transfection with SV-40 large T-antigen (Zavizion et al. 1996). The BME-UV1 cells were kindly provided by Antonella Baldi, Department of Health, Animal Science and Food Safety (VESPA), University of Milan, Italy. Cells were routinely cultivated into $75-\mathrm{cm}^{2}$ tissue culture flasks (Costar, Corning, NY), in a mixture of 50\% DMEM-F12, 30\% RPMI1640, and 20\% NCTC-135 (Sigma-Aldrich, St. Louis, MO), supplemented with $10 \%$ fetal bovine serum, $0.1 \%$ lactose, $0.1 \%$ lactalbumin hydrolysate, $1.2 \mathrm{~m} M$ glutathione, $1 \mu \mathrm{g} / \mathrm{mL}$ of insulin, $5 \mu \mathrm{g} / \mathrm{mL}$ of transferrin, 1 $\mu \mathrm{g} / \mathrm{mL}$ of hydrocortisone, $0.5 \mu \mathrm{g} / \mathrm{mL}$ of progesterone, $10 \mu \mathrm{g} / \mathrm{mL}$ of L-ascorbic acid, and antibiotics (penicillin, $100 \mathrm{IU} / \mathrm{mL}$; streptomycin, $100 \mu \mathrm{g} / \mathrm{mL}$ ). All medium supplements were from Sigma-Aldrich. The cells were maintained at $37^{\circ} \mathrm{C}$ in a humidified $5 \% \mathrm{CO}_{2}$ incubator until confluence. Cells used in the present work were at passage numbers between 39 and 41 .

\section{Experimental Design}

To examine the role of CLA on oxidative status of bovine mammary gland, BME-UV1 cells were resuspended in complete culture medium to a concentration of $5 \times 10^{5}$ cells $/ \mathrm{mL}$ and dispensed into wells of 6 -well and 96-well tissue culture plates. After $24 \mathrm{~h}$ of incubation at $37^{\circ} \mathrm{C}$ in an atmosphere of $5 \% \mathrm{CO}_{2}$, the medium was removed and cells were treated with complete medium containing $50 \mu M$ cis-9,trans-11 CLA (c9,t11 CLA), trans-10, cis-12 CLA (t10,c12 CLA), and CLA mixture (50\% c9,t11 and 50\% t10,c12 CLA). To monitor cellular uptake of CLA isomers, cells were treated as described above and samples of cells and culture medium were collected at 0,3 , and $48 \mathrm{~h}$ from CLA addition for lipid extraction and FA analyses.

To study the cellular antioxidant response, the role of CLA in cell protection against the oxidative stress and the molecular mechanism involved, cell samples were collected for cell extracts and mRNA extraction after $48 \mathrm{~h}$ from addition of CLA. To test the potential protection of CLA against hydrogen peroxide $\left(\mathrm{H}_{2} \mathrm{O}_{2}\right)$ induced oxidative stress, cells were treated as described above followed by incubation at $37^{\circ} \mathrm{C}$ for $3 \mathrm{~h}$ with $\mathrm{H}_{2} \mathrm{O}_{2}$ $(50$ and $100 \mu M$ ) and cell viability was determined. The CLA concentration $(50 \mu M)$ was used because at $50 \mu M$ concentration, no differences were observed in cell viability between CLA treatments and control. Moreover, 
previous studies have shown that higher concentrations of CLA induce apoptosis in the mammary cells (Keating et al., 2008; Wang et al., 2014). Finally, the physiological concentration of CLA in human sera is in the range of 10 to $70 \mu M$ (De la Torre et al., 2005). Therefore, the concentration of $50 \mu \mathrm{M}$ used in the present study is close to physiological levels. The CLA isomers were purchased from Larodan (Malmo, Sweden).

The experiments included at least 3 replicates per treatment and were repeated at least twice.

\section{CLA Uptake by Cells}

Lipid Extraction. Total lipids of cell pellet and culture medium were extracted according to a modified Folch et al. (1957) procedure. Briefly, the whole cell pellet (almost 1 million cells) or $0.1 \mathrm{~mL}$ of culture medium were dissolved in a screw-cap tube with 12 $\mathrm{mL}$ of chloroform/methanol $(2 / 1 \mathrm{vol} / \mathrm{vol})$ with $2 \mu \mathrm{g}$ of vitamin $\mathrm{E}$ added and left in the dark at room temperature for $60 \mathrm{~min}$. Then $4 \mathrm{~mL}$ of water was added and tubes were centrifuged at $900 \times g$ for 60 min at $4^{\circ} \mathrm{C}$ to obtain 2 phases. After centrifugation the lower phase containing chloroform and total lipids was collected. The extracted fat was dried at $30^{\circ} \mathrm{C}$ by means of a rotary evaporator device.

Preparative Procedure for HPLC Analysis. Preparation of FFA was obtained by mild saponification according to Melis et al. (2001): lipid extracts were dissolved in $5 \mathrm{~mL}$ of ethanol, $0.1 \mathrm{~mL}$ of desferal in water $(25 \mathrm{mg} / \mathrm{mL}), 1 \mathrm{~mL}$ of a $25 \%$ water solution of ascorbic acid, $0.5 \mathrm{~mL}$ of $10 \mathrm{~N} \mathrm{KOH}$, left in the dark at room temperature for $14 \mathrm{~h}$. Then $10 \mathrm{~mL}$ of n-hexane and $7 \mathrm{~mL}$ of water were added and the solution was acidified by adding $37 \% \mathrm{HCl}$, to a $\mathrm{pH} 3$ to 4 . Samples were vortexed for $1 \mathrm{~min}$, then centrifuged at $900 \times g$ for $60 \mathrm{~min}$ at $4^{\circ} \mathrm{C}$. Finally, solvent was evaporated and the residue was dissolved in $0.5 \mathrm{~mL}$ of a mixture acetic acid $0.14 \%$ ( $\mathrm{vol} / \mathrm{vol})$ in acetonitrile.

Diode Array Detector HPLC Analysis of FFA. Analysis of FFA was carried out with a Varian Dual Prostar 210 liquid chromatograph (Varian, Palo Alto, CA) equipped with a diode array detector. A OmniSpher 5 C18 column, $5 \mu \mathrm{m}$ particle size (Chrompack, Middelburg, the Netherlands), $250 \times 4.6 \mathrm{~mm}$ was used with a mobile phase of $\mathrm{CH}_{3} \mathrm{CN} / \mathrm{H}_{2} \mathrm{O} / \mathrm{CH}_{3} \mathrm{COOH}$ $(70 / 30 / 0.12, \mathrm{vol} / \mathrm{vol} / \mathrm{vol})$ and a flow rate of $1.5 \mathrm{~mL} /$ min. Unsaturated nonconjugated FA were detected at $200 \mathrm{~nm}$, conjugated diene FA at $234 \mathrm{~nm}$. The CLA isomers were recognized by using a commercial standard mixture of c9,t11 CLA and t10,c12 CLA and pure c9,t11 CLA or t10,c12 CLA standards (Matreya Inc., Pleasant Gap, PA). Because CLA metabolites are not commercially available, their recognition was obtained by diode array spectra and by comparison with published HPLC profiles (Melis et al., 2001).

\section{Cellular Antioxidant Response and Cell Protection}

Thiol Redox Status and Antioxidant Enzymes. The thiol redox status of BME-UV1, cultured under the conditions described above, was assessed by measuring the content of glutathione (GSH/GSSH), the content of nicotinamide adenine dinucleotide phosphate (NADPH), and the activity of $\gamma$-glutamyl-cysteine ligase $(\gamma \mathbf{G C L})$.

Cytoplasmic superoxide dismutase (SOD), glutathione peroxidase $(\mathbf{G P x} \mathbf{1})$, glutathione S-transferase (GST), and glutathione reductase (GR) activities were determined in BME-UV1 cultured under the conditions described above and were measured using colorimetric assays.

For the determination of GSH/GSSG and NADPH, adherent cells were detached using trypsin/EDTA solution and centrifuged at $4,500 \times g$ for $5 \mathrm{~min}$ at $4^{\circ} \mathrm{C}$. The pellet was resuspended in $200 \mu \mathrm{L}$ of PBS and lysed by sonication at $100 \mathrm{~W}$ for $60 \mathrm{~s}$, centrifuged $(15,000 \times g$ for $5 \mathrm{~min}$ at $4^{\circ} \mathrm{C}$ ), and stored at $-20^{\circ} \mathrm{C}$ until analysis. In cell extracts, NADPH and GSH/GSSH concentrations were determined by colorimetric assays (BioAssay Systems, Hayward, CA). Optical density was measured by a spectrophotometer at 405 and 540, respectively.

The $\gamma$ GCL activity was determined by a fluorescence assay as described by Chen et al. (2010). The BMEUV1 cells were detached using trypsin/EDTA solution and centrifuged at $4,500 \times g$ for $5 \mathrm{~min}$ at $4^{\circ} \mathrm{C}$. The pellet was resuspended in $100 \mu \mathrm{L}$ of TES/SB buffer (wt/ vol, 1/4) consisting of $20 \mathrm{~m} M$ Tris, $1 \mathrm{~m} M$ EDTA, 250 $\mathrm{m} M$ sucrose, $20 \mathrm{~m} M$ sodium borate, and $2 \mathrm{~m} M$ serine. The cells were sonicated at $100 \mathrm{~W}$ for $60 \mathrm{~s}$ and then centrifuged at $10,000 \times g$ at $4^{\circ} \mathrm{C}$ for $10 \mathrm{~min}$. The supernatants were collected and centrifuged again at 15,000 $\times g$ at $4^{\circ} \mathrm{C}$ for $20 \mathrm{~min}$. The supernatants were collected and the protein concentrations were determined using a BCA Protein Assay Kit from Pierce (Rockford, IL), with BSA used as the standard. For the $\gamma$ GCL activity assay, aliquots of $30 \mu \mathrm{L}$ supernatant were mixed with $30 \mu \mathrm{L}$ of $\gamma \mathrm{GCL}$ reaction cocktail (400 $\mathrm{m} M$ Tris, 40 $\mathrm{m} M$ ATP, $40 \mathrm{~m} M$ L-glutamic acid, $2 \mathrm{~m} M$ EDTA, 20 $\mathrm{m} M$ sodium borate, $2 \mathrm{~m} M$ serine, and $40 \mathrm{mM} \mathrm{MgCl} 2$ ). Following incubation at $37^{\circ} \mathrm{C}$ for $5 \mathrm{~min}, 30 \mu \mathrm{L}$ of cysteine solution (30 $\mathrm{m} M$; dissolved in TES/SB buffer) was added and the mixtures were incubated at $37^{\circ} \mathrm{C}$ for $13 \mathrm{~min}$. The enzymatic reaction in the mixture, was stopped by precipitating proteins with $200 \mathrm{mM}$ 5 -sulfosalicylic acid. After placing on ice for $20 \mathrm{~min}$, the mixtures were centrifuged at $2,000 \times g$ at $4^{\circ} \mathrm{C}$ for 10 min. Following centrifugation, $20 \mu \mathrm{L}$ of each superna- 
tant containing $\gamma$-glutamylcysteine $(\gamma \mathbf{G C})$ was added to a 96 well plate designed for fluorescence detection. For each assay, $20 \mu \mathrm{L}$ of $\gamma \mathrm{GC}$ standards, containing $5 \mu \mathrm{L}$ of $\gamma \mathrm{GCL}$ reaction cocktail $[5 \mu \mathrm{L}$ of 5 -sulfosalicylic acid $(200 \mathrm{mM}), 5 \mu \mathrm{L}$ of $\mathrm{H}_{2} \mathrm{O}$, and $5 \mu \mathrm{L}$ of $\gamma \mathrm{GC}$ standard solution $(0,20,40,60,80,100,120$, and 140 $\mu M$ in TES/SB buffer)], was added to each well of the same 96-well plate to generate a standard curve. Next, $180 \mu \mathrm{L}$ of 2,3-naphthalenedicarboxyaldehyde (NDA) was added to each well. Following incubation in the dark at room temperature for $30 \mathrm{~min}$, the formation of NDA- $\gamma$ GC was measured (472 nm excitation/528 nm emission) using a fluorescent plate reader (Multimode Detector DTX 880, Beckman Coulter Inc., Fullerton, $\mathrm{CA})$. The production of $\gamma \mathrm{GC}$ in each sample was calculated using the standard curve. Values were expressed in micromoles per microgram of protein.

To determine GPx-1, GST, GR, and SOD activity, after incubation, the plates were placed in ice, the monolayers were mechanically detached with a scraper and the cells were sonicated (100 W for $60 \mathrm{~s})$, centrifuged $\left(15,000 \times g\right.$ for $5 \mathrm{~min}$ at $\left.4^{\circ} \mathrm{C}\right)$, and stored at $-80^{\circ} \mathrm{C}$ until analysis. The enzymatic activities were determined by colorimetric assays (BioAssay Systems, Hayward, CA). Optical density was measured by a spectrophotometer at 340,405 and $450 \mathrm{~nm}$, respectively.

RNA Isolation and Real-Time PCR. The mRNA abundance of bovine antioxidant enzymes (GPx-1, GSR, GST, and SOD) was assayed in BMEUV1 cultured under the conditions described above and were carried out by real-time PCR.

To isolate total RNA, BME-UV1 cells were seeded in 6 -well tissue culture plate at the concentration of $5 \times$ $10^{5}$ cells $/ \mathrm{mL}$ in complete medium containing $10 \%$ fetal bovine serum. Total RNA was extracted by QIAzol Lysis Reagent (Qiagen, Hilden, Germany), according to the manufacturer's instructions and stored at $-80^{\circ} \mathrm{C}$. The RNA was quantified using Quant-iT RNA assay Kit (Invitrogen, Carlsbad, CA) and fluorescence was measured at excitation/emission of $644 / 673 \mathrm{~nm}$. The integrity of the RNA was checked by visualization of $18 \mathrm{~S}$ and $28 \mathrm{~S}$ ribosomal bands on an agarose gel. One microgram of total RNA was reverse transcribed using a Quantitect reverse transcription kit (Qiagen) in a total volume of $20 \mu \mathrm{L}$ on a PCR Express thermal cycler (Hybaid, Ashford, UK). Quantitative SYBR Green real-time PCR was performed following the manufacturer's recommendations using LightCycler (Roche Applied Science, Indianapolis, IN). To account for possible variation related to cDNA input or the presence of PCR inhibitors, the endogenous reference gene RPS9 was simultaneously quantified for each sample, and data were normalized accordingly. In Table 1 the specific characteristics of primers used for the real-time PCR are shown. The PCR products were subjected to a melting curve analysis on the LightCycler and subsequently 2\% agarose/Tris-borate-EDTA gel electrophoresis to confirm amplification specificity and amplicon size. To allow relative quantification after PCR, standard curves were constructed from the standard reactions for each target and housekeeping genes by plotting crossing point $(\mathbf{C p})$ values (i.e., the cycle number at which the fluorescence signal exceeds background versus log cDNA dilution). The $\mathrm{Cp}$ readings for each of the unknown samples where then used to calculate the amount of either the target or housekeeping relative to the standard, using the second derivative maximum method with the LightCycler analysis software 3.5 (Roche Applied Science).

Reactive Oxygen Species and Thiobarbituric Acid Reactive Substance Production. To determine reactive oxygen species (ROS) concentration, cells were washed twice with PBS and incubated with $20 \mu M 2^{\prime}, 7^{\prime}$-dichlorodihydrofluorescin diacetate probe in PBS at $37^{\circ} \mathrm{C}$ for $40 \mathrm{~min}$. Fluorescence was measured at $485 \mathrm{~nm}$ (excitation) and $535 \mathrm{~nm}$ (emission) wavelengths on a microplate reader (Multimode Detector DTX 880, Beckman Coulter Inc.).

For the determination of thiobarbituric acid reactive substances (TBARS), adherent cells were detached

Table 1. DNA sequences of bovine sense and antisense primers used for real-time PCR analysis

\begin{tabular}{|c|c|c|c|}
\hline Gene $^{1}$ & Primer & $\begin{array}{l}\text { Temperature of } \\
\text { annealing, }{ }^{\circ} \mathrm{C}\end{array}$ & Sequence \\
\hline GPx1 forward & CTTCCCCTGCAACCAGTTTG & 60 & NM_174076 \\
\hline GPx1 reverse & GGCAATTCAGGATCTCCTCGTT & & \\
\hline GR reverse & CTCGTCCAAGCATCTCTTCCT & & \\
\hline CuZn SOD forward & GAAGAGAGGCATGTTGGAGA & 57 & NM_174615 \\
\hline CuZn SOD reverse & CCAATTACACCACGAGCCAA & & \\
\hline RPS9 forward & GGCGGCTCGTCCGTATC & 60 & XN_864261 \\
\hline RPS9 reverse & AATCTTCAGGCCCAGGATGTAATC & & \\
\hline
\end{tabular}

${ }^{1} \mathrm{GPx} 1$ = glutathione peroxidase, GR = glutathione reductase, GST = glutathione-S-transferase, and SOD = superoxide dismutase. 
using trypsin/EDTA solution and centrifuged at 4,500 $\times g$ for $5 \mathrm{~min}$ at $4^{\circ} \mathrm{C}$. The pellet was resuspended in 200 $\mu \mathrm{L}$ of PBS and lysed by 2 cycles of sonication at $100 \mathrm{~W}$ for $30 \mathrm{~s}$, centrifuged $\left(15,000 \times g\right.$ for $5 \mathrm{~min}$ at $\left.4^{\circ} \mathrm{C}\right)$, and stored at $-20^{\circ} \mathrm{C}$ until analysis. In cell extracts TBARS concentrations were determined by colorimetric assays (BioAssay Systems, Hayward, CA). Optical density was measured by a spectrophotometer at $340 \mathrm{~nm}$.

Cell Viability. The BME-UV1 cells were seeded into 96 -well microplates at an optimal density $\left(5 \times 10^{5}\right.$ cells $/ \mathrm{mL}$ ) and were grown with different CLA isomers (c9,t11 CLA, t10,c12 CLA, and CLA mixture) for 48 $\mathrm{h}$. Then cells were incubated at $37^{\circ} \mathrm{C}$ for $3 \mathrm{~h}$ with different concentrations (50 and $100 \mu M$ ) of $\mathrm{H}_{2} \mathrm{O}_{2}$. Cell viability before and after incubation with $\mathrm{H}_{2} \mathrm{O}_{2}$ was determined using an XTT assay with a Cell Proliferation kit II \{XTT: sodium 30-[1-(phenylaminocarbonyl)-3,4tetrazolium]-bis (4-methoxy-6-nitro) benzene sulfonic acid hydrate; Roche Applied Science\} according to the manufacturer's instructions. For each treatment, after 3 h of exposure to $\mathrm{H}_{2} \mathrm{O}_{2}, 50 \mu \mathrm{L}$ of XTT labeling mixture was added to each well. After $4 \mathrm{~h}$ incubation at $37^{\circ} \mathrm{C}$, absorbance was measured at $450 \mathrm{~nm}$. Background absorbance was subtracted from each value. Results were expressed as optical density $\left(\mathrm{OD}_{450}\right)$.

\section{Statistical Analysis}

All data of the experiment are presented as least squares means and standard error of the means. The data were analyzed by ANOVA using Statistica-7 Software package (Stat Soft Inc., Tulsa, OK). The significance of the differences was assessed by the Fisher's least significant difference (LSD) test. Significance was declared at $P<0.05$.

\section{RESULTS}

\section{Incorporation of CLA Isomers in Cell Lipids}

The cellular uptake of FA was determined at 3 and $48 \mathrm{~h}$ incubation in the presence of c9,t11 CLA, t10,c12 CLA, and CLA mix. The disappearance of the FA from the medium and the appearance in the cells was used as a measure of FA uptake. As shown in Table 2 , the average cellular uptake of FA during the 3-h incubation was $23,22.85$, and $19.52 \%$ for c9,t11 CLA, t10,c12 CLA, and CLA mix, respectively. After 48 h FA uptake increased to $73.25,71.88$, and $78.60 \%$ for c $9, \mathrm{t} 11$ CLA, t10,c12 CLA, and CLA mix, respectively. This is also confirmed by a simultaneous decrease of CLA isomers from the culture medium. All FA were highly incorporated. Cells cultured with c9,t11 CLA led to the highest cellular contents of total FA. During the 3 and $48 \mathrm{~h}$ incubation, a progressive enrichment of C18:3 c6,c9,t11 and C18:3 c6,t10,c12 as CLA metabolites was observed within cells. No significance variation was noted concerning the differences between each FA for uptake rates.

\section{Thiol Redox Status}

Oxidized and Reduced Glutathione. The levels of nonenzymatic antioxidants like GSH are depicted in Figure 1. Quantitative determination of reduced and oxidized GSH (Figure 1A and B, respectively) showed an increase $(P<0.01)$ of reduced GSH in cells treated with t10,c12 CLA, c9,t11 CLA, and CLA mix compared with control; in particular, t10,c12 CLA showed an increase $(P<0.01)$ of reduced GSH compared with c9,t11 CLA and CLA mix. No differences in the level of oxidized GSH were noted for cells treated with CLA isomers compared with the control culture.

Quantitative Determination of NADPH. Concentrations of a redox coenzyme NADPH are reported in Figure 1C. Cells treated with t10,c12 CLA showed higher levels $(P<0.01)$ of NADPH compared with other CLA treatments and control.

$\gamma$-Glutamyl-Cysteine Ligase Activity. Thiol redox status was assessed by measuring $\gamma$ GCL activity (Figure 1D). After the $48 \mathrm{~h}, \mathrm{CLA}$ isomers induced a strong antioxidant response by increasing $(P<0.01)$ intracellular $\gamma \mathrm{GCL}$ activity compared with the control. No differences of $\gamma$ GCL activity were observed for different CLA treatments.

Quantification of Activity and mRNA Expression Levels of the Antioxidant Enzymes. The enzymatic activities of GPx1, GR, GST, and SOD in cell lysates are shown in Figure 2 (panels A, B, C and $\mathrm{D}$, respectively). From this figure, it is evident that the activity of GPx1 showed an increase $(P<0.01)$ in cells treated with CLA compared with control. The GPx1 activity was greater $(P<0.01)$ in $\mathrm{c} 9$,t11 CLA cells with respect to t10,c12 CLA and CLA mix.

The GR activity decreased $(P<0.01)$ in cells treated with t10,c12 CLA and CLA mix compared with control cells. In cells treated with c9,t11 CLA, the GR activity was not different compared with control but showed a decrease $(P<0.05)$ compared with other CLA treatments (t10,c12 and mix).

The GST activity showed an increase $(P<0.05)$ in cells treated with t10,c12 CLA compared with control. The activity of SOD was increased $(P<0.01)$ by CLA compared with control.

In Figures 3A, 3B, 3C, and 3D, the mRNA expression of GPx1, GR, GST, and SOD, respectively, is reported. The levels of gene expression of GPx1, GR, GST, and SOD mRNA did not show any differences between CLA 


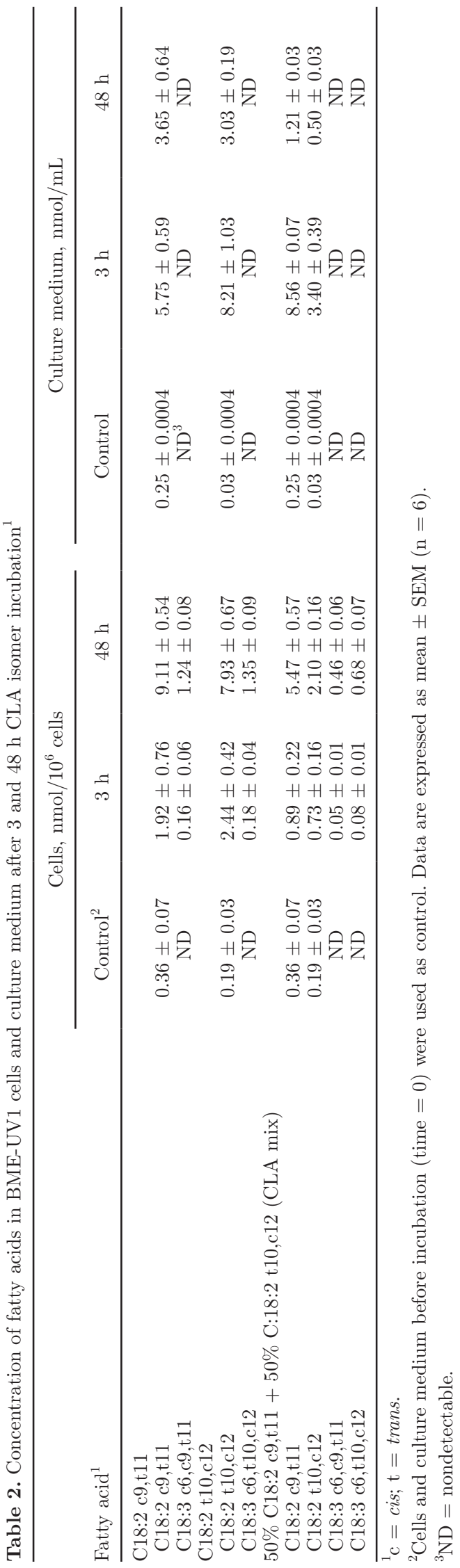

treatments and control. No differences were observed among treatments with different CLA isomers (c9,t11, $\mathrm{t} 10, \mathrm{c} 12$, and mix).

Intracellular ROS and TBARS. The GSH is recognized as the main intracellular antioxidant, it maintains the redox status of the cell and is related to intracellular ROS levels. For this reason, intracellular ROS production was assessed in cells supplemented with CLA isomers. At $48 \mathrm{~h}$ (Figure 4A), ROS showed a 8.6, 10.6, and $19 \%$ reduction in cells treated with c9,t11 CLA $(P<0.05)$, t10,c12 CLA $(P<0.05)$, and CLA mix $(P<0.01)$, respectively, compared with the control. The intracellular ROS levels in cells treated with CLA mix showed a decrease $(P<0.05)$ compared with the other 2 CLA treatments.

Cell concentrations of TBARS are shown in Figure 4B. All CLA treatments reduced $(P<0.01)$ TBARS levels compared with untreated cells.

\section{Protection of Cells Against Oxidative Stress}

Cell viability was carried out using the XTT assay and was evaluated after $48 \mathrm{~h}$ of CLA exposure. As shown in Table 3, no CLA treatments reduced the cell viability, and no differences were observed between treatments with different CLA isomers (c9,t11 CLA, t10,c12 CLA, and CLA mix).

To evaluate and to compare the potential protection of different CLA isomers against $\mathrm{H}_{2} \mathrm{O}_{2}$-induced oxidative stress, we assessed cell viability by the XTT test after $3 \mathrm{~h}$ to $\mathrm{H}_{2} \mathrm{O}_{2}$ exposure. As shown in Table 3, all CLA isomers were able to enhance cell resistance against oxidative stress at $48 \mathrm{~h}$. Cell resistance with c9,t11 CLA, t10,c12 CLA, and CLA mix increased to 122,114 , and $126 \%$, respectively, compared with the control.

\section{DISCUSSION}

The present study investigated the effect of the main biologically active CLA isomers, c9,t11 and t10,c12 CLA, on the cellular antioxidant response of bovine mammary gland epithelial cells (BME-UV1) and examined whether CLA isomers could play a role in cell protection against oxidative stress.

The CLA supplementation increased their concentration in the cells, and BME-UV1 cultured with CLA treatments did not produce differences in uptake rates of different CLA isomers. Therefore, the uptake rate of the tested FA was not influenced by their geometric structures. Results reveal that mammary cells readily picked up the tested FA. Accumulation of total CLA metabolites in CLA treated cultures were time dependent, and the main metabolites were 18:3 isomers (C18:3 

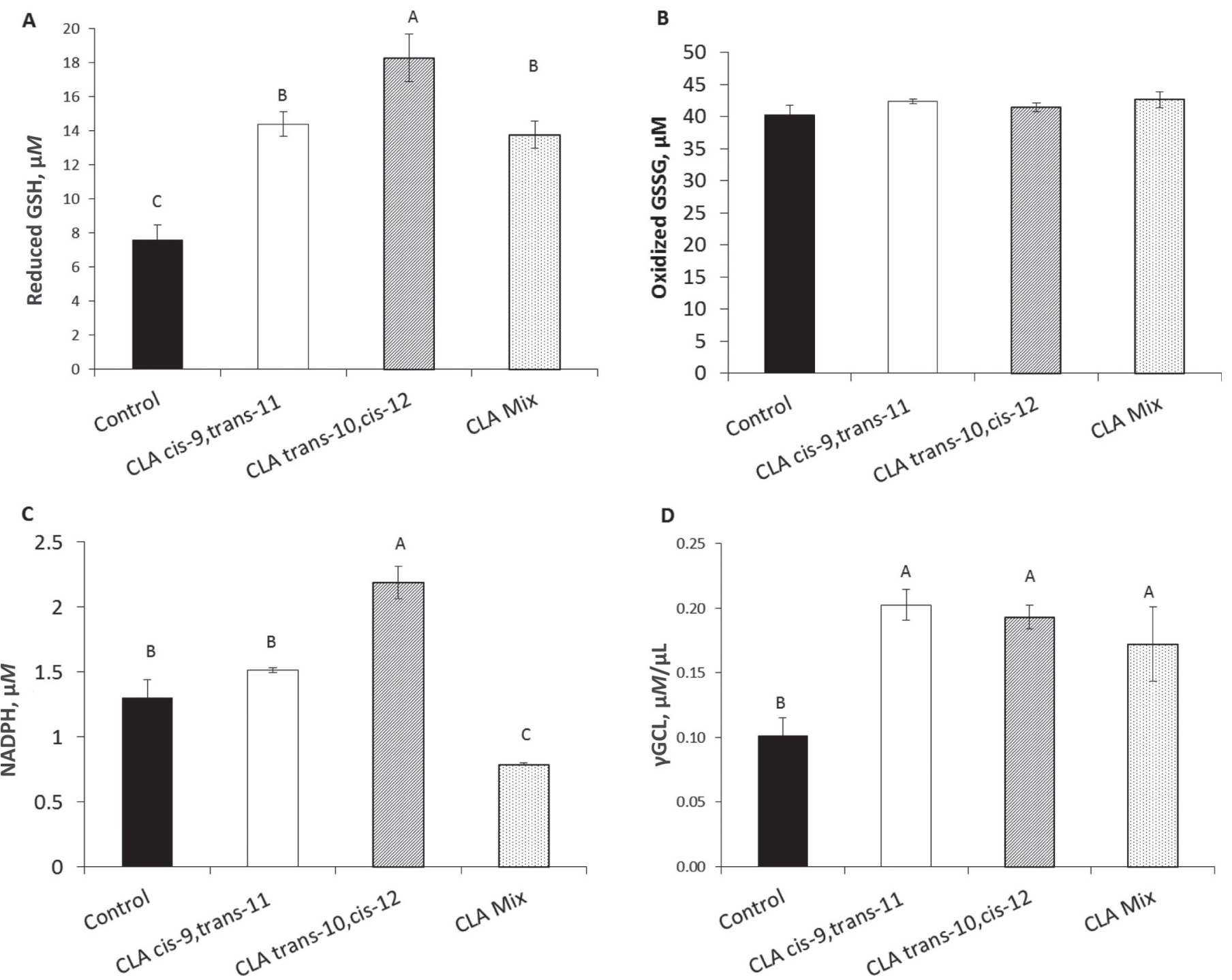

Figure 1. Intracellular concentrations of reduced (GSH; A) and oxidized (GSSG; B) glutathione, NADPH (C), and $\gamma$-glutamate cysteine ligase $(\gamma \mathrm{GCL} ; \mathrm{D})$ activity in BME-UV1 cells after $48 \mathrm{~h}$ of CLA isomer exposure. Data are reported as least squares means \pm standard error of the mean $(\mathrm{n}=6)$. Significant differences between the control group and treatments and among treatments are represented by different letters $\left({ }^{\mathrm{A}, \mathrm{B}} \mathrm{P}<0.01\right)$. CLA $\operatorname{mix}=50 \%$ cis- 9, trans $-11 / 50 \%$ trans -10, cis- 12.

$\mathrm{c} 6, \mathrm{c} 9, \mathrm{t} 11$ and $\mathrm{C} 18: 3 \mathrm{c} 6, \mathrm{t} 10, \mathrm{c} 12)$. To date, this is the first time that metabolites of delta-6-desaturation of CLA isomers are identified in bovine mammary epithelial cells. These findings are in agreement with Meadus et al. (2014) who identified metabolites of t10,c12 and c9,t11 CLA after their addiction to 3T3-adipocyte cultures and observed a delta-6-desaturase (D6D Fads2) activity, which added a c6 double bond to the CLA isomers to make 18:3 isomers. Those authors reported that the different CLA treatments formed unique metabolites and the c9,t11 CLA isomer was preferentially converted by delta- 6 desaturation (FADs2) followed by elongase (Elov5) to a conjugated 20:3-c8,c11,t13. Alternatively, the t10,c12 CLA was only desaturated to conjugated 18:3-c6,t10,c12, possibly being an unsuitable substrate for further elongation (Banni et al., 2004). In rodents and in humans, metabolites originated by peroxisomal $\beta$-oxidation of CLA isomers have also been reported (Banni et al., 2004). In the present study, conjugated 16:2 isomers were not identified, probably due to the short time of incubation.

To reduce oxidative damage, the cells modulate the redox status as a cytoprotective strategy. Results of the present study clearly showed that the exposure of cells to $50 \mu \mathrm{M}$ CLA isomers for $48 \mathrm{~h}$ produced a significant intracellular GSH increase, matched by high concentration of NADPH and an increase of $\gamma$-glutamylcysteine ligase activity. This was mainly observed in cells 
A

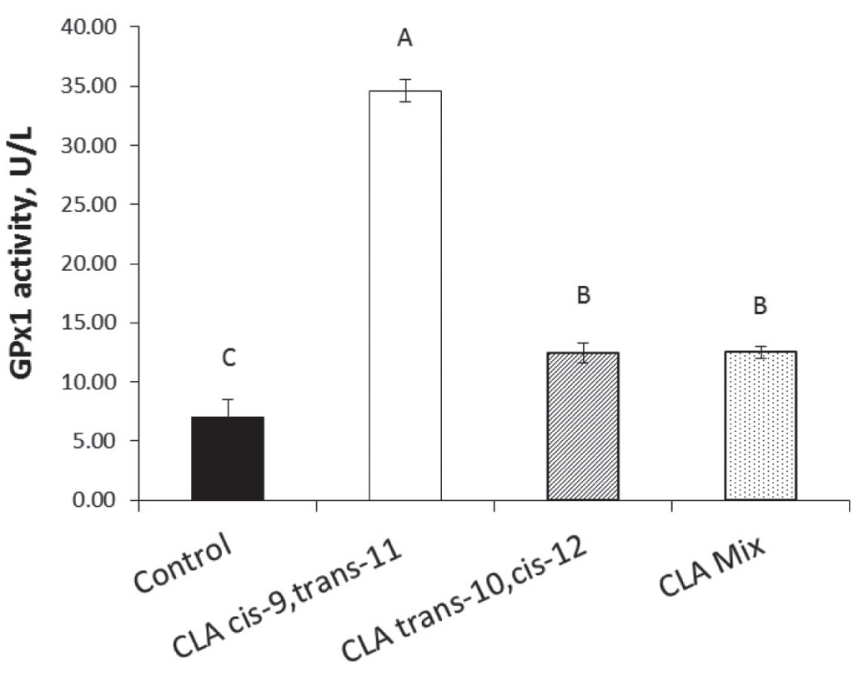

C

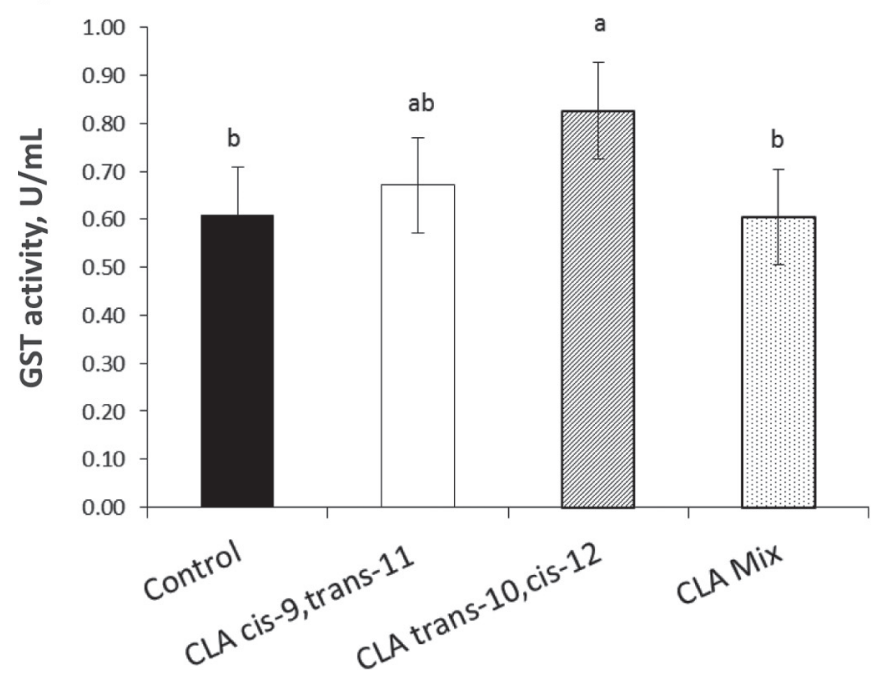

B

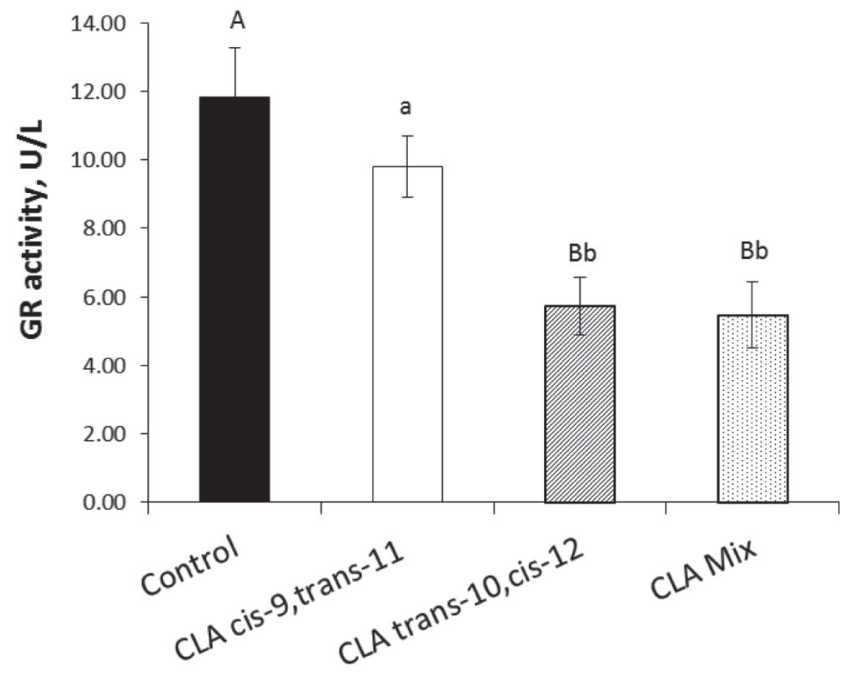

D

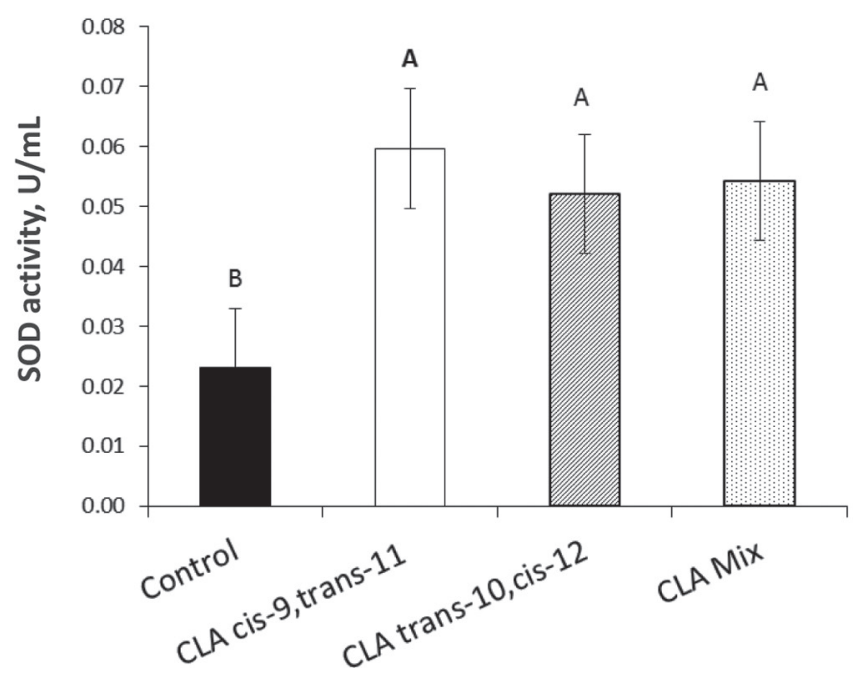

Figure 2. Intracellular levels of glutathione peroxidase (GPx1; A), glutathione reductase (GR) (B), glutathione-S-transferase (GST; C), and superoxide dismutase (SOD; D) activity in BME-UV1 cells after $48 \mathrm{~h}$ of CLA isomer exposure. Data are reported as least squares means \pm SEM $(\mathrm{n}=6)$. Significant differences between the control group and treatments and among treatments are represented by different letters $\left({ }^{\mathrm{A}, \mathrm{B}} P\right.$ $\left.<0.01 ;{ }^{\mathrm{a}, \mathrm{b}} \mathrm{P}<0.05\right)$. CLA $\operatorname{mix}=50 \%$ cis- 9 , trans $-11 / 50 \%$ trans -10, cis -12 .

treated with t10,c12 CLA isomer. It was difficult to understand the low concentration of NADPH in CLA mixture treated cells.

In this study, CLA ability to elicit cytoprotective effects (enhancement of cellular GSH and NADPH availability, and $\gamma$ GCL activity) was shown for the first time in bovine mammary gland, and this is in agreement with literature data showing the antioxidant potential property of CLA (Jang et al., 2004; Fagali and Catalá, 2008; Chinnadurai et al., 2013). Similar results were obtained also by Arab et al. (2006) in an in vitro study using human skin fibroblasts treated with 8 different FA, including c9,t11 CLA. In that study, GSH synthesis was upregulated by c9,t11 CLA, mainly through an in- duction of $\gamma$ GCL. The GSH plays a primary role in the maintenance of intracellular redox homeostasis by affording protection against reactive oxygen and nitrogen species as well as electrophilic xenobiotics. Under normal cellular redox conditions, the major portion of this redox regulator is in the form of GSH, whereas GSSG concentration increases during oxidative stress. Replenishment of depleted GSH levels during oxidative stress, by de novo synthesis, is of great physiological relevance due to the multiplicity of the functional roles of GSH (Weijl et al., 2004). Its homeostasis is modulated to a large extent by 2 enzymes: $\gamma$-glutamylcysteine cysteine ligase, which catalyzes the committed step in GSH biosynthesis, and $\gamma$-glutamyltranspeptidase, which initi- 
A

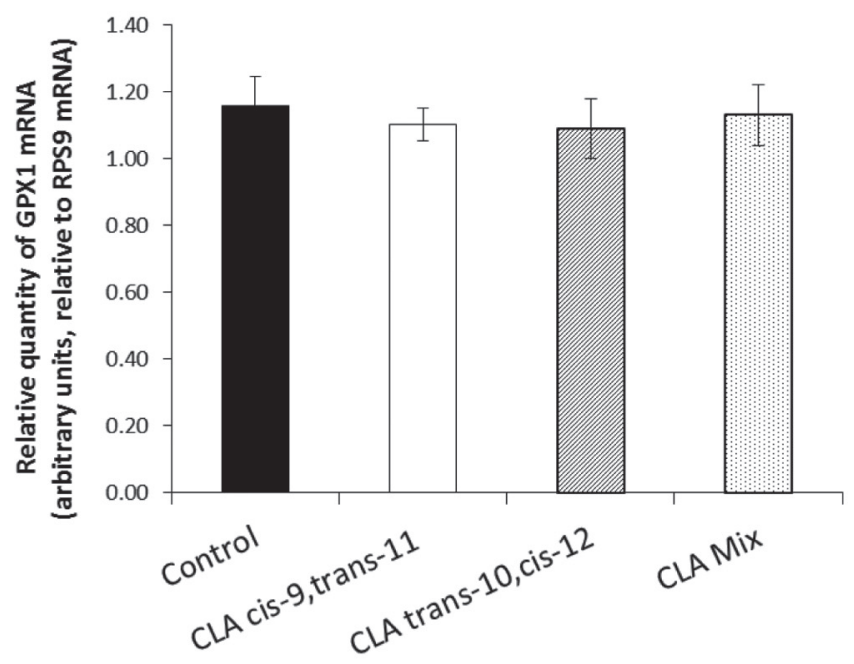

C

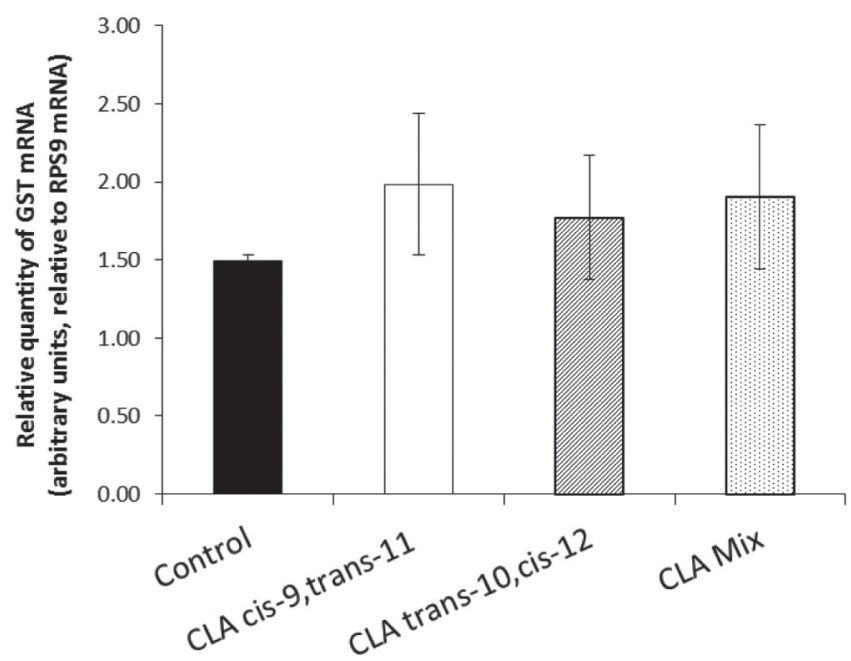

B

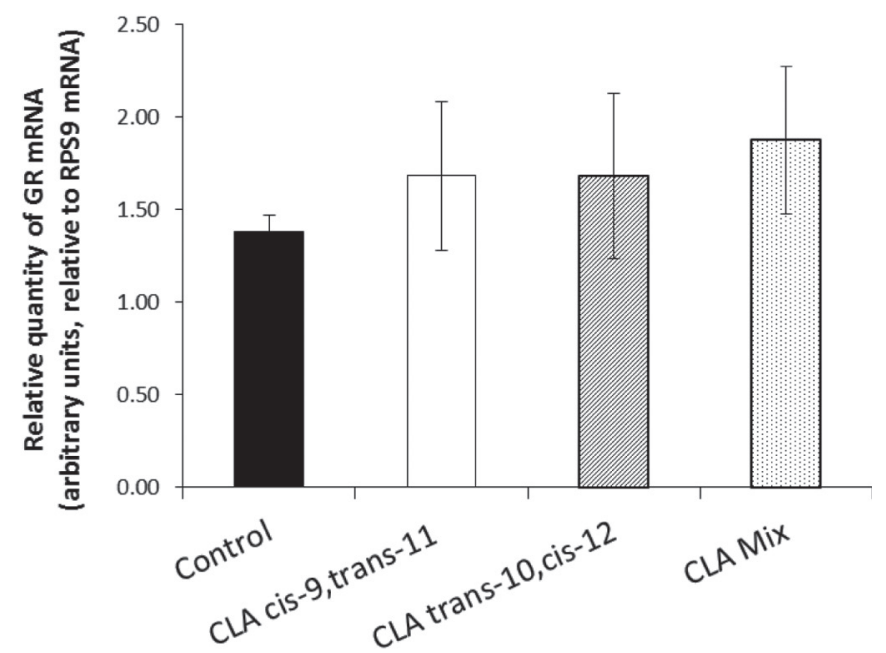

D

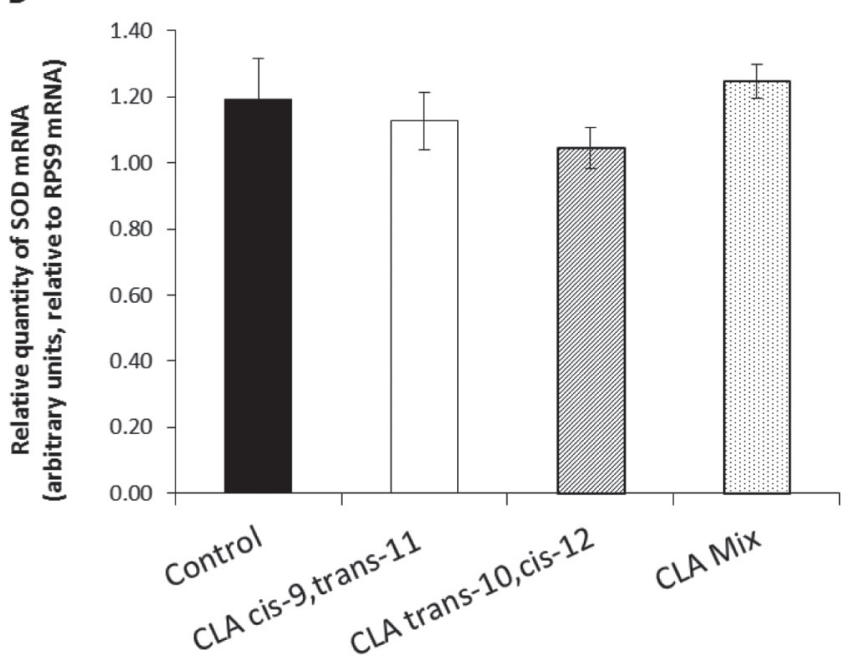

Figure 3. Messenger RNA abundance of glutathione peroxidase (GPx1; A), glutathione reductase (GR; B), glutathione-S-transferase (GST; $\mathrm{C}$ ), and superoxide dismutase (SOD; D) in BME-UV1 cells after $48 \mathrm{~h}$ of CLA isomer exposure. Data are reported as least squares means \pm SEM $(\mathrm{n}=6)$. CLA $\operatorname{mix}=50 \%$ cis- 9, trans $-11 / 50 \%$ trans- $10-$ cis -12 .

ates GSH reclamation. Above all an induction of $\gamma \mathrm{GCL}$ is characteristic of an antioxidant response (Lee et al., 2003; Rahman, 2005). Moreover, NADPH is essential in GSH recycling and related antioxidant functions, and the ratio of the reduced to total pyridine nucleotide pool is generally accepted as an indicator of the cellular redox status (Adams et al., 2001). Toroser et al. (2006) reported that NADPH has regulatory effects on $\gamma \mathrm{GCL}$ activity and increased maximal $\gamma$ GCL activity by up to $93 \%$ in the kidney of rats, so it may be possible to modulate de novo GSH synthesis and to control GSH homeostasis using amounts of pyridine dinucleotide phosphates.

Based on results of the present study with enhanced GSH and NADPH availability and $\gamma$ GCL activity, we suggest that in BME-UV1 cells the upregulated GSH synthesis by CLA may be determined by the induction of $\gamma$ GCL by NADPH, mainly in cells treated with t10,c12 CLA isomer. These findings are consistent with literature data indicating enhanced GSH content via the enhanced activation and induction of $\gamma \mathrm{GCL}$ in human skin fibroblasts and in MRL/MpJ-Fasl mice after CLA administration (Arab et al., 2006; Bergamo et al., 2006, 2007). In particular, Arab et al. (2006) clearly demonstrated that only CLA and not other unsaturated FA were responsible in improving GSH synthesis.

In addition to nonenzymatic antioxidants as GSH, the cell can counteract oxidative stress by the antioxidant enzyme system such as SOD and various GSH-related enzymes (GPx1, GST, and GR). In the present study, 
Table 3. Cell viability of BME-UV1 cells $(\mathrm{n}=6)$ observed, respectively, after $48 \mathrm{~h}$ of CLA isomer supplementation, and after $3 \mathrm{~h}$ of $\mathrm{H}_{2} \mathrm{O}_{2}$ treatment $(50 \text { and } 100 \mu M)^{1}$

\begin{tabular}{|c|c|c|c|c|c|c|}
\hline Supplementation & LSM & SEM & \multicolumn{2}{|c|}{$50 \mu M \mathrm{H}_{2} \mathrm{O}_{2}(3 \mathrm{~h})$} & \multicolumn{2}{|c|}{$100 \mu M \mathrm{H}_{2} \mathrm{O}_{2}(3 \mathrm{~h})$} \\
\hline Control & 1.55 & 0.02 & 1.32 & 0.03 & 1.27 & 0.01 \\
\hline CLA trans- 10, cis- 12 & 1.68 & 0.02 & $1.50^{*}$ & 0.02 & $1.39^{*}$ & 0.02 \\
\hline CLA mix & 1.68 & 0.04 & $1.65^{* *}$ & 0.04 & $1.52^{* *}$ & 0.02 \\
\hline
\end{tabular}

${ }^{1}$ Absorbance was measured at $450 \mathrm{~nm}$, and data are reported as optical density $\left(\mathrm{OD}_{450}\right)$.

${ }^{*} P<0.05 ;{ }^{* *} P<0.01$ : mean values were significantly different from those of the control group.

CLA isomers induced an increase of SOD, GPx1, and GST activity and a decrease of GR activity. Hence, enhancing SOD, GPx1, and GST activity the CLA treatment may offer higher protection to the cells against oxidants. Similar results were reported by in vivo studies on laboratory animals fed with CLA at high levels (Ip et al., 1991; Santos Zago et al., 2007; Chinnadurai et al., 2013). Those studies showed that administration of CLA to the diet of rats increased catalase, SOD, and GST enzyme activities, which finally led to an improvement in the antioxidative process.

The decrease of GR activity induced by CLA treatment may be ascribed to the higher presence of reduced GSH in the cells possibly due to de novo GSH synthesis by GCL, so it is not necessarily GSSG recycling to GSH.

The absence of gene expression modifications in antioxidant enzymes suggests that the CLA isomers improve the antioxidative enzyme systems through a posttranscriptional regulation. Sadi and Sadi (2010) reported that redox-sensitive proteins execute their functions via kinases, phosphatases, and transcription factors influencing the steady state levels of antioxidant enzymes. Therefore, cells may sense, transduce, and translate the oxidant signals into appropriate cellular responses depending on the cellular redox state.

Other than antioxidants, we also measured ROS and TBARS. Results indicated that the presence of CLA was associated with a low induction of ROS production. Therefore, high GSH content maintains the redox status of the cell, in this way, it is related to low intracellular ROS levels. In addition, CLA induced GSH synthesis, without any induction of ROS production. As the ability of CLA to enhance GSH content relies on $\gamma$ GCL induction, and the main inducers of this activity are ROS, PPAR- $\gamma$, and NADPH (Wild et al., 1999; Toroser et al., 2006). These results confirm the hypothesis that the induction of $\gamma$ GCL by CLA might be mediated through NADPH or, as suggested also by Arab et al.
A

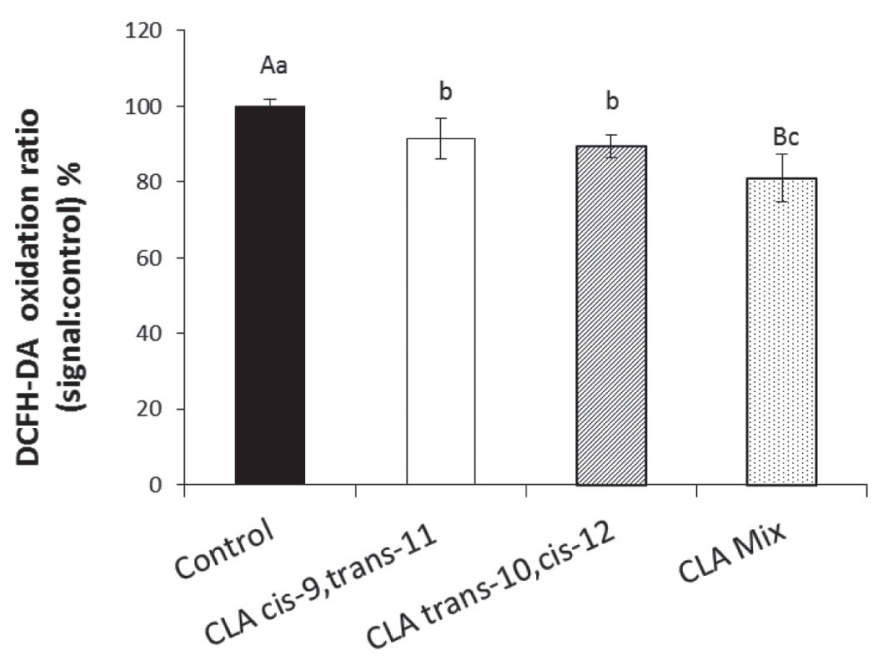

B

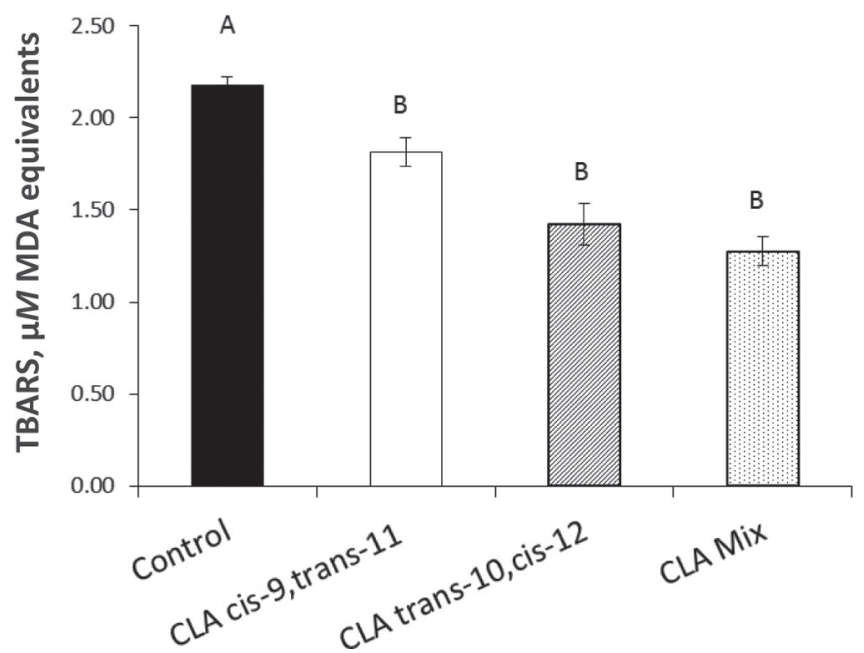

Figure 4. Intracellular production of reacting oxygen species (ROS; A) and thiobarbituric acid reactive substances (TBARS; B) level in BME-UV1 cells after $48 \mathrm{~h}$ of conjugated linoleic acid (CLA) isomer exposure. Data are reported as least squares means \pm SEM $(\mathrm{n}=6)$. Significant differences between the control group and treatments and among treatments are represented by different letters $\left({ }^{\mathrm{A}, \mathrm{B}} P<0.01 ;{ }^{\mathrm{a}, \mathrm{b}} P<\right.$ $0.05)$. CLA $\operatorname{mix}=50 \%$ cis- 9, trans $-11 / 50 \%$ trans- 10 , cis- 12 . 
(2006), through the activation of transcription factors of PPAR.

The TBARS were chosen because they have been hypothesized to represent a composite number of lipid oxidative-end products, including malondialdehyde. Therefore, the measurement of TBARS is indicative of lipid peroxidation and a biomarker of oxidative damage. In this study, CLA isomer supplementation decreased cellular concentration of TBARS. Thus, the association of this biomarker with low ROS induction seems to confirm the improvement of cell oxidative status. Fagali and Catalá (2008) clearly indicated that CLA isomers and not linoleic acid or its methyl ester provide protection against free radicals.

Finally, the measurement of cell viability in the presence of $\mathrm{H}_{2} \mathrm{O}_{2}$ was used as a further test to check cell protection. From results of the present study it is clear that CLA protected cells against oxidative damage induced by $\mathrm{H}_{2} \mathrm{O}_{2}$, and this protection seems to be mediated by the high level of GSH. In addition, Arab et al. (2006) reported that among 8 FA tested, CLA was the only PUFA able to have a protective action against oxidative insult in human skin fibroblasts.

The protective effect of a CLA-rich diet has already been described in laboratory animals (Chinnadurai et al., 2013), and the potential improving of energy balance and metabolic status observed in bovine fed with CLA-rich diets (van Knegsel et al., 2014) could be also related to the enhancement of the thiol redox status described here.

\section{CONCLUSIONS}

Findings of the present study corroborate an antioxidant role of CLA, in particular of the t10,c12 CLA isomer, by developing a significant elevated redox status in cells. In the present study, we showed that CLA isomers are potent inducers of GSH synthesis. The induction of $\gamma$-GCL by CLA could be mediated through NADPH and CLA has a protective action due to GSH synthesis without lipoperoxidation. Moreover, the enhancement of anti-oxidative capacity and cell protection against oxidative damages in mammary cells may be due to a direct effect of CLA on cell integrity. The potential role of CLA in improving energy balance and metabolic status observed in dairy cow might be also related to the enhancement of the thiol redox status described here. Moving from these findings, we propose that under physiological stress situations, as the periparturient period, the improvement of the intracellular redox homeostasis by CLA treatment could be a preparative mechanism against the relative oxidative stress caused by energy imbalance due to nutritional status, adipose mobilization, and changes in hormone profiles. Based on the data presented here, further in vivo studies are necessary to fully understand the potential role of CLA on the metabolism and antioxidant capabilities of transition cows and to show how these CLA isomers may reduce incidence of oxidative stress and related diseases in early lactation.

\section{ACKNOWLEDGMENTS}

The study was financially supported by BASF SE, Ludwigshafen, Germany.

\section{REFERENCES}

Adams, J. D. Jr., L. K. Klaidman, M. L. Chang, and J. Yang. 2001. Brain oxidative stress-Analytical chemistry and thermodynamics of glutathione and NADPH. Curr. Top. Med. Chem. 1:473-482. Andreoli, M. F., P. G. Illesca, M. A. González, and C. A. Bernal. 2010. Conjugated linoleic acid reduces hepatic steatosis and restores liver triacylglycerol secretion and the fatty acid profile during protein repletion in rats. Lipids 45:1035-1045.

Arab, K., A. Rossary, L. Soulère, and J. P. Steghens. 2006. Conjugated linoleic acid, unlike other unsaturated fatty acids, strongly induces glutathione synthesis without any lipoperoxidation. Br. J. Nutr. 96:811-819.

Banni, S., A. Petroni, M. Blasevich, G. Carta, L. Cordeddu, E. Murru, M. P. Melis, A. Mahon, and M. A. Belury. 2004. Conjugated linoleic acids (CLA) as precursors of a distinct family of PUFA. Lipids 39:1143-1146.

Bauman, D. E., and J. M. Griinari. 2003. Nutritional regulation of milk fat synthesis. Annu. Rev. Nutr. 23:203-227.

Bauman, D. E., J. W. I. Perfield, K. J. Harvatine, and L. H. Baumgard. 2008. Regulation of fat synthesis by conjugated linoleic acid: Lactation and the ruminant model. J. Nutr. 138:403-409.

Baumgard, L. H., B. A. Corl, and D. E. Bauman. 2000a. Effect of CLA isomers on fat synthesis during growth and lactation. Pages 180190 in 62nd Proc. Cornell Nutr. Conf. Feed Manuf., Ithaca, NY.

Baumgard, L. H., B. A. Corl, D. A. Dwyer, A. Saebø, and D. E. Bauman. 2000b. Identification of the conjugated linoleic acid isomer that inhibits milk fat synthesis. Am. J. Physiol. Regul. Integr. Comp. Physiol. 278:R179-R184.

Bergamo, P., D. Luongo, F. Maurano, G. Mazzarella, R. Stefanile, and M. Rossi. 2006. Conjugated linoleic acid enhances glutathione synthesis and attenuates pathological signs in MRL/MpJ-Fas (lpr) mice. J. Lipid Res. 47:2382-2391.

Bergamo, P., F. Maurano, and M. Rossi. 2007. Phase 2 enzyme induction by conjugated linoleic acid improves lupus-associated oxidative stress. Free Radic. Biol. Med. 43:71-79.

Bernabucci, U., B. Ronchi, N. Lacetera, and A. Nardone. 2005. Influence of body condition score on relationships between metabolic status and oxidative stress in periparturient dairy cows. J. Dairy Sci. 88:2017-2026.

Castañeda-Gutiérrez, E., T. R. Overton, W. R. Butler, and D. E. Bauman. 2005. Dietary supplements of two doses of calcium salts of conjugated linoleic acid during the transition period and early lactation. J. Dairy Sci. 88:1078-1089.

Chen, C. N., H. M. Brown-Borg, S. G. Rakoczy, D. A. Ferrington, and L. V. Thomposon. 2010. Aging impairs the expression of the catalytic subunit of glutamate-cysteine ligase in soleus muscle under stress. J. Gerontol. A Biol. Sci. Med. Sci. 65:129-137.

Chinnadurai, K., H. K. Kanwal, A. K. Tyagi, C. Stanton, and P. Ross. 2013. High conjugated linoleic acid enriched ghee (clarified butter) increases the antioxidant and antiatherogenic potency in female Wistar rats. Lipids Health Dis. 12:121.

Da Silva Marineli, R., A. y Castro Marques, C. P. Busch Furlan, and M. R. Maróstica Jr.. 2012. Antioxidant effects of the combina- 
tion of conjugated linoleic acid and phytosterol supplementation in Sprague-Dawley rats. Food Res. Int. 49:487-493.

De la Torre, A., E. Debiton, D. Durand, J. M. Chardigny, O. Berdeaux, O. Loreau, C. Barthomeuf, D. Bauchart, and D. Gruffat. 2005. Conjugated linoleic acid isomers and their conjugated derivatives inhibit growth of human cancer cell lines. Anticancer Res. 25:3943-3949.

den Hartigh, L. J., C. Y. Han, S. Wang, M. Omer, and A. Chait. 2013. 10E,12Z-conjugated linoleic acid impairs adipocyte triglyceride storage by enhancing fatty acid oxidation, lipolysis, and mitochondrial reactive oxygen species. J. Lipid Res. 54:2964-2978.

Drackley, J. K. 1999. ADSA Foundation Scholar Award. Biology of dairy cows during the transition period: The final frontier? J. Dairy Sci. 82:2259-2273.

Fagali, N., and A. Catalá. 2008. Antioxidant activity of conjugated linoleic acid isomers, linoleic acid and its methyl ester determined by photoemission and DPPH techniques. Biophys. Chem. 137:56-62.

Folch, J., M. Lees, and G. H. Sloane-Stanley. 1957. A simple method for the isolation and purification of total lipids from animal tissues. J. Biol. Chem. 226:497-509.

Goff, J. P., and R. L. Horst. 1997. Physiological changes at parturition and their relationship to metabolic disorders. J. Dairy Sci. 80:1260-1268

Grummer, R. R. 1993. Etiology of lipid-related metabolic disorders in periparturient dairy cows. J. Dairy Sci. 76:3882-3896.

Hötger, K., H. M. Hammon, C. Weber, S. Görs, A. Tröscher, R. M. Bruckmaier, and C. C. Metges. 2013. Supplementation of conjugated linoleic acid in dairy cows reduces endogenous glucose production during early lactation. J. Dairy Sci. 96:2258-2270.

Ip, C., S. F. Chin, J. A. Scimeca, and M. W. Pariza. 1991. Mammary cancer prevention by conjugated dienoic derivative of linoleic acid. Cancer Res. 51:6118-6124.

Jang, I. S., H. Y. Yang, and Y. H. Ko. 2004. Effect of conjugated linoleic acid on intestinal and hepatic antioxidant enzyme activity and lipid peroxidation in broiler chickens. Asian-australas. J. Anim. Sci. 17:1162-1167.

Keating, A. F., F. Q. Zhao, K. A. Finucane, D. R. Glimm, and J. J. Kennelly. 2008. Effect of conjugated linoleic acid on bovine mammary cell growth, apoptosis and stearoyl Co-A desaturase gene expression. Domest. Anim. Endocrinol. 34:284-292.

Lee, J. M., M. J. Calkins, K. Chan, Y. W. Kan, and J. A. Johnson. 2003. Identification of the NF-E2-related factor-2-dependent genes conferring protection against oxidative stress in primary cortical astrocytes using oligonucleotide microarray analysis. J. Biol. Chem. 278:12029-12038.

Mackle, T. R., J. K. Kay, M. J. Auldist, A. K. H. McGibbon, B. A. Philpott, L. H. Baumgard, and D. E. Bauman. 2003. Effects of abomasal infusion of conjugated linoleic acid on milk fat concentration and yield form pasture-fed dairy cows. J. Dairy Sci. 86:644-652.

Meadus, W. J., P. Vahmani, P. Duff, D. C. Rolland, T. D. Turner, and M. E. Dugan. 2014. Metabolism of CLA isomers, c9,t11 and t10,c12, in adipocyte cultures and their effect on delta- 6 desaturase expression. Abstract no. 481 in Proc. 10th World Congress on Genetics Applied to Livestock Production. Vancouver (BC), Canada.

Melis, M. P., E. Angioni, G. Carta, E. Murru, P. Scanu, S. Spada, and S. Banni. 2001. Characterization of conjugated linoleic acid and its metabolites by RP-HPLC with diode array detector. Eur. J. Lipid Sci. Technol. 103:617-621.
Odens, L. J., R. Burgos, M. Innocenti, M. J. VanBaale, and L. H. Baumgard. 2007. Effects of varying doses of supplemental conjugated linoleic acid on production and energetic variables during the transition period. J. Dairy Sci. 90:293-305.

Pappritz, J., U. Meyer, R. Kramer, E. Weber, G. Jahreis, J. Rehage, G. Flachowsky, and S. Dänicke. 2011. Effects of long-term supplementation of dairy cow diets with rumen-protected conjugated linoleic acids (CLA) on performance, metabolic parameters and fatty acid profile in milk fat. Arch. Anim. Nutr. 65:89-107.

Rahman, I. 2005. Regulation of glutathione in inflammation and chronic lung diseases. Mutat. Res. 579:58-80.

Sadi, G., and O. Sadi. 2010. Antioxidants and regulation of antioxidant enzymes by cellular redox status. Turkish J. Scientific Rev. 3:95-107.

Santos-Zago, L. F., A. P. Botelho, and A. C. de Oliveira. 2007. Supplementation with commercial mixtures of conjugated linoleic acid in association with vitamin $\mathrm{E}$ and the process of lipid autoxidation in rats. Lipids 42:845-854.

Selberg, K. T., A. C. Lowe, C. R. Staples, N. D. Luchini, and L. Badinga. 2004. Production and metabolic responses of periparturient Holstein cows to dietary conjugated linoleic acid and trans-octadecenoic acids. J. Dairy Sci. 87:158-168.

Singh, S. P., S. Häussler, J. F. L. Heinz, B. Saremi, B. Mielenz, J. Rehage, S. Dänicke, M. Mielenz, and H. Sauerwein. 2014. Supplementation with conjugated linoleic acids extends the adiponectin deficit during early lactation in dairy cows. Gen. Comp. Endocrinol. 198:13-21.

Sordillo, L. M., G. A. Contreras, and S. L. Aitken. 2009. Metabolic factors affecting the inflammatory response of periparturient dairy cows. Anim. Health Res. Rev. 10:53-63.

Toroser, D., C. S. Yarian, W. C. Orr, and R. S. Sohal. 2006. Mechanisms of gamma-glutamylcysteine ligase regulation. Biochim. Biophys. Acta 1760:233-244.

van Knegsel, A. T. M., G. J. Remmelink, S. Jorjong, V. Fievez, and B. Kemp. 2014. Effect of dry period length and dietary energy source on energy balance, milk yield, and milk composition of dairy cows. J. Dairy Sci. 97:1499-1512.

von Soosten, D., U. Meyer, M. Piechotta, G. Flachowsky, and S. Dänicke. 2012. Effect of conjugated linoleic acid supplementation on body composition, body fat mobilization, protein accretion, and energy utilization in early lactation dairy cows. J. Dairy Sci 95:1222-1239

Wang, H., H. Liu, J. Liu, K. Zhao, C. Wang, and W. Yang. 2014 High-level exogenous trans10, cis12 conjugated linoleic acid plays an anti-lipogenesis role in bovine mammary epithelial cells. Anim. Sci. J. 85:744-750.

Weijl, N. I., T. J. Elsendoorn, E. G. Lentjes, G. D. Hopman, A. Wipkink-Bakker, A. H. Zwinderman, F. J. Cleton, and S. Osanto. 2004. Supplementation with antioxidant micronutrients and chemotherapy-induced toxicity in cancer patients treated with cisplatin-based chemotherapy: A randomised, doubleblind, placebocontrolled study. Eur. J. Cancer 40:1713-1723.

Wild, A. C., H. R. Moinova, and R. T. Mulcahy. 1999. Regulation of gammaglutamylcysteine synthetase subunit gene expression by the transcription factor Nrf2. J. Biol. Chem. 274:33627-33636.

Zavizion, B., M. van Duffelen, W. Schaeffer, and I. Politis. 1996. Establishment and characterization of a bovine mammary epithelial cell line with unique properties. In Vitro Cell. Dev. Biol. Anim. $32: 138-148$. 